IZA DP No. 6785

Subcontracting and the Size and Composition of the Informal Sector: Evidence from Indian Manufacturing

Ana I. Moreno-Monroy

Janneke Pieters

Abdul A. Erumban

August 2012 


\title{
Subcontracting and the Size and Composition of the Informal Sector: Evidence from Indian Manufacturing
}

\author{
Ana I. Moreno-Monroy \\ University of Groningen \\ Janneke Pieters \\ $I Z A$ \\ Abdul A. Erumban
University of Groningen
}

Discussion Paper No. 6785

August 2012

IZA

P.O. Box 7240

53072 Bonn

Germany

Phone: +49-228-3894-0

Fax: +49-228-3894-180

E-mail: iza@iza.org

\begin{abstract}
Any opinions expressed here are those of the author(s) and not those of IZA. Research published in this series may include views on policy, but the institute itself takes no institutional policy positions.

The Institute for the Study of Labor (IZA) in Bonn is a local and virtual international research center and a place of communication between science, politics and business. IZA is an independent nonprofit organization supported by Deutsche Post Foundation. The center is associated with the University of Bonn and offers a stimulating research environment through its international network, workshops and conferences, data service, project support, research visits and doctoral program. IZA engages in (i) original and internationally competitive research in all fields of labor economics, (ii) development of policy concepts, and (iii) dissemination of research results and concepts to the interested public.
\end{abstract}

IZA Discussion Papers often represent preliminary work and are circulated to encourage discussion. Citation of such a paper should account for its provisional character. A revised version may be available directly from the author. 
IZA Discussion Paper No. 6785

August 2012

\section{ABSTRACT}

\section{Subcontracting and the Size and Composition of the Informal Sector: Evidence from Indian Manufacturing}

This paper analyzes the relationship between formal sector subcontracting and the evolution of the informal sector using nationally representative survey data of Indian manufacturing enterprises for the period 1995-2006. In these years of fast economic growth, subcontracting by formal enterprises gained importance, while the informal sector continued to account for 90 per cent of total manufacturing employment. In order to contrast between a 'modernization' and a 'stagnation' view on formal-informal production linkages, we test whether subcontracting is related to the size of more modern versus more traditional segments of the informal sector. The results show that formal sector subcontracting is positively related to the size of the informal sector only for the most modern informal activities, supporting the view that subcontracting is related to informal sector modernization. We find no support for the claim that the continued expansion of very traditional informal activities is related to increased outsourcing by formal manufacturing enterprises.

JEL Classification: $\quad$ O14, O17, L60

Keywords: informal sector, formal sector, subcontracting, manufacturing, India

Corresponding author:

Janneke Pieters

IZA

P.O. Box 7240

53072 Bonn

Germany

E-mail: pieters@iza.org 


\section{Introduction}

In developing countries, a substantial proportion of employment and output generation are concentrated in the informal sector (Schneider et al., 2010). One of the key aspects in understanding the development of the informal sector is its interaction with the formal sector (Davies and Thurlow, 2010; Hart, 1973; Ranis and Stewart, 1999; Weeks, 1975). An important way in which formal enterprises interact with informal enterprises is through subcontracting part of their production process to informal enterprises. Although subcontracting has gained relevance in times of increased competition brought about by trade liberalization and globalization (ILO and WTO, 2009), little is known about the relationship it bears with the evolution of the informal sector.

This relationship is the focus of the present paper, which analyzes the Indian manufacturing industry during India's economic boom years 1994-2006, in which subcontracting by formal enterprises gained importance, while informal sector employment kept growing and remained at almost 90 per cent of total manufacturing employment. Two contrasting views that appear in the literature on informality are analyzed empirically by capturing the diversity of informal sector activities through a measure of informal sector modernity.

The first view, hereafter referred to as the stagnation view, contends that formal enterprises subcontract the most labor-intensive production activities to traditional informal enterprises, in order to minimize labor costs. Due to intense pressure for cost competition exerted on informal enterprises, the linkages between formal and informal enterprises result in a downward spiral of wages, worsening labor conditions, and the recreation of the survivalist characteristics of informal enterprises (see Portes, 1994; Tokman, 1978). If this is the case, subcontracting linkages will be strongest between the formal sector and the most traditional segment of the informal sector, such that an increase in formal sector subcontracting nourishes traditional informal activities, thus contributing to stagnation of the informal sector.

The second view, labeled the modernization view, holds that subcontracting is a vehicle for the modernization of the informal sector. Formal enterprises, therefore, only establish subcontracting relationships with modern informal enterprises, which can not only reduce the costs of production, but also ensure certain standards regarding quality of output and delivery times. Growth of the modern segment of the informal sector, or modernization of the informal sector, is positively related to the growth of the formal 
sector due to production linkages between the two (Marjit, 2003; Ranis and Stewart, 1999).

This paper uses nationally representative enterprise-level survey data for formal and informal manufacturing for the period 1994-2006. The survey data are aggregated to the state-industry level to estimate the relationship between the size of the informal sector and formal sector subcontracting, where the effect is moderated by the degree of modernity of the informal sector. Indian manufacturing offers a compelling opportunity for the analysis of the relationship between subcontracting and the evolution of the informal sector. The informal sector in India is large and persistent, accounting for about 90 per cent of employment and 40 per cent of value added in manufacturing in 2005-06. Furthermore, competitive pressure in the manufacturing sector has increased as a consequence of the reforms undertaken in the late 1980s and early 1990s that abolished licensing requirements for most industries and the liberalization of international trade and foreign investment (Kotwal et al., 2011). The regulation of labor markets, however, has been left largely untouched, and constitutes an important difference between formal and informal enterprises. ${ }^{1}$ Pressure to cut costs and increase flexibility, together with strict labor laws affecting only formal enterprises, form clear incentives for formal enterprises to subcontract activities to the informal sector (Mazumdar and Sarkar, 2008; Ramaswamy, 1999; Siggel, 2010). Although the increase in subcontracting practices has been an important development in Indian manufacturing in the last two decades, little is known about its relationship with the evolution of the informal sector as a whole. Existing evidence is based on small surveys and specific case studies and remains inconclusive (Knorringa, 1994; Sahu, 2010; Uchikawa, 2011).

The data show that subcontracting by formal enterprises has increased substantially during this period, and did so disproportionately in state-industries where the informal sector is most modern. At the same time, informal sector employment expanded but did not show a clear pattern of either modernization or stagnation, as the largest share of employment remains in the most traditional activities. ${ }^{2}$ The empirical results show that

\footnotetext{
${ }^{1}$ The terms 'formal' and 'informal' are not used officially in India. The official distinction is between organized (registered) and unorganized (unregistered) enterprises, where the former consists of enterprises employing 10 or more workers using power, and 20 or more workers without using power. In this article, reference is made to the registered enterprises as formal and all other enterprises - those in the unregistered segment - as informal.

${ }^{2}$ This might explain why the ongoing expansion of the informal sector in India is less growth enhancing, as observed by de Vries et al. (2012).
} 
growth of formal sector subcontracting is positively related to expansion of the most modern informal activities, while no such relationship is found for less modern and most traditional segments. These findings support the modernization view of the informal sector. Although in Indian manufacturing, the most modern informal sector activities account for only a small share of informal employment, the results clearly indicate that persistence of a large traditional segment in informal manufacturing is not the result of increased subcontracting by the formal sector.

In the next section, the concept of informal sector heterogeneity and the two views on the effects of formal sector subcontracting are further discussed. This provides the rationale for analyzing the effect of subcontracting on the informal sector by distinguishing modern and traditional informal sectors segments. The section also discusses existing evidence for the case of India. Section 3 introduces the data and empirical model, followed by a description of the growth and modernity of the informal sector and trends in formal sector subcontracting in section 4. Section 5 discusses the main results and robustness checks, and section 6 concludes the paper.

\section{Informal sector heterogeneity and the effect of formal sector subcontracting}

\subsection{Informal sector heterogeneity and modernization}

The informal sector is highly diverse. An 'informal enterprise' can be one consisting of a single worker performing simple manual work in the worker's own household with no machinery. It can also be an enterprise that operates in a plant, employing as much as 10 hired workers and using machinery. Evidently these two types of enterprises are not the same, even though they can both be labeled as 'informal'. For this reason, it is difficult to find a unique defintion of an 'informal enterprise' that can account for this heterogeneity.

Ranis and Stewart (1999) have proposed a relevant distinction between the traditional and modern segments of the informal sector, based on a number of characteristics of the informal enterprises that compose them. To understand this, it is useful to think of the informal enterprises along a continuum of 'modernity' dimensions, as represented in Figure 1. At the very bottom of the distribution are traditional informal enterprises that have extremely low or no capital usage, make no use of hired labor, operate within the premises of a household or do not have a fixed location, and undertake very low valueadded activities such as small-scale retail sales, artisanal manufacturing production or personal services. At the very top of the distribution are the informal enterprises that 
make use of some capital, have a fixed location outside the household, produce standardized goods and services making use of low- and medium-skilled labor, and offer competitive wages that are comparable those offered in the formal sector. Informal enterprises at the very top of the distribution can be indistinguishable from formal Small and Medium Enterprises (SMEs), save the fact that they do not comply with all the legal regulations faced by the formal sector. ${ }^{3}$

Figure 1: Distribution of informal enterprises along a modernity continuum

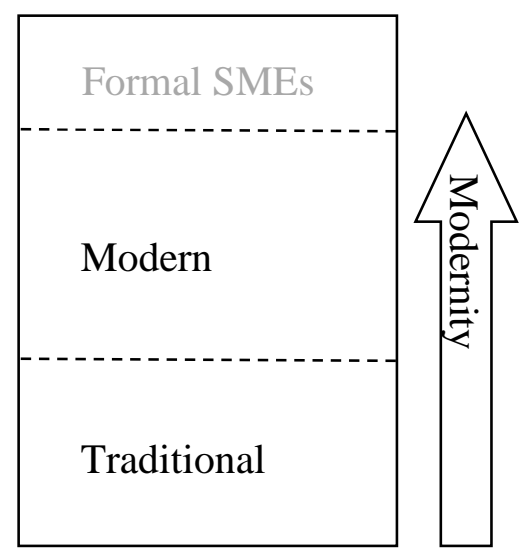

Modernity dimensions

-Capital per worker and level of capitalization

-Number of (hired) workers

-Technology and installed capacity

-Wages and profits

-Location

-Complexity of goods and services produced

In the process of economic development, the modernization of the informal sector implies an increase of the relative size of the modern informal segment and a decline of the traditional segment. The existence of production linkages between informal and formal enterprises can speed up or deter the modernization of the informal sector (Ranis and Stewart, 1999). In the case of formal-informal subcontracting linkages, these effects on the evolution of the informal sector can be summarized into two contrasting views found in the literature: the stagnation view and the modernization view.

\subsection{Two contrasting views on the effects of subcontracting}

According to the stagnation view, formal enterprises wishing to reduce labor costs subcontract activities to informal enterprises. By their superior status in terms of size and capital, formal enterprises are able to impose stringent conditions on informal enterprises

\footnotetext{
${ }^{3}$ The labor-market counterpart to this modern/traditional distinction is the distinction between informal employment as a last resort option for workers facing open unemployment, and informal employment as a deliberate choice of entrepreneurs who want to avoid costly regulations of setting up businesses, find informal activities more profitable than formal activities or simply want to have more freedom in terms of working schedules (Fields, 2005; Perry et al, 2007; Gunther and Launov, 2011; Maloney, 2004; Kucera and Roncolato, 2008).
} 
regarding prices, thus extracting most of the value added and leaving informal enterprises stagnated in a survivalist mode (Moser, 1978; Portes, 1994; Portes et al., 1989; Sanyal, 2007; Tokman, 1978). In fact, formal enterprises can benefit from the "race-to-thebottom” in terms of labor costs in the informal sector, as it directly translates into higher profitability from subcontracting. As stagnant, survivalist informal enterprises are part of the traditional segment of the informal sector, an increase in the incidence of subcontracting would result in expansion of the traditional segment and thus work against the modernization of the informal sector.

A second view on the effects of subcontracting, referred to as the modernization view, holds that formal enterprises engage in subcontracting relationships only with modern informal enterprises. An explanation for this can be offered based on three complementary aims that formal enterprises pursue when engaging in subcontracting. The first one is to minimize costs so that the price of the subcontracted activity is as low as possible. The second one is to maximize the quality of the subcontracted product so as not to compromise the quality standards of the final product. The third one is to minimize the risk of vertically disintegrating the production process, so that the decision of subcontracting does not compromise the delivery time of the final product. Therefore, formal enterprises take into account not only the difference in costs between in-house production and subcontracting but also the productive and technological capacity of potential suppliers (Wattanapruttipaisan, 2002).

The modernization view is described in Ranis and Stewart (1999). Under the premise that formal enterprises have intermediate linkages (including subcontracting) only with modern informal enterprises, they show how formal sector growth can lead to modernization of the informal sector. Growth of formal sector output or an increase in the subcontracting-intensity of formal sector production leads to the expansion of the modern informal segment. Through expansion of output, demand for labor in this segment increases. If labor is drawn from the traditional informal segment (or if traditional enterprises become modern), a decline in the share of the traditional segment simultaneously follows from the expansion in formal sector output. In a similar vein, Marjit (2003) emphasizes segmentation within the informal sector and argues that only the capital-intensive segment is complementary to the formal sector. In his general equilibrium model, the formal sector uses an intermediate input produced by the capitalintensive (modern) segment of the informal sector. Output growth in the formal sector leads to an expansion of this capital-intensive informal segment through increased 
demand for its output, and to a contraction of the labor-intensive (traditional) segment through relocation of labor from informal to formal sector.

There is descriptive evidence for Kenya and a number of West African countries showing that, in line with the modernization view, informal enterprises with more capital, higher productivity, and more highly educated workers are more likely to have a forward production link with the formal sector (Arimah, 2001; Boehme and Thiele, 2012; House, 1984). It is not yet clear in the literature, however, whether informal enterprises become more (less) productive as a result of their production link with the formal sector, or whether only more (less) productive informal enterprises have linkages with the formal sector in the first place. Enterprise-level studies that address this question typically cannot establish the direction of causality, due to lack of longitudinal enterprise-level data. The present study does not aim at establishing the effect of subcontracting on firm performance, but rather focuses on the effect on the size of different segments of the informal sector. The issue of causality is further discussed in the Section 3.

\subsection{Existing evidence for India}

Although there is a growing empirical literature on the informal manufacturing sector in India (e.g., Ghani et al., 2011; Mukim, 2011), there are no studies to date that consider the differences between modern and traditional segments and the modernization of the Indian informal manufacturing sector. Existing case studies of subcontracting and the informal sector draw a rather mixed picture. Based on a field survey of some 350 informal enterprises in rural West Bengal, Maiti (2008) documents a fast increase during India's post-reform period in the share of enterprises tied to a master enterprise or middleman for work orders and /or raw materials. Knorringa (1994), in his study of the Agra shoe-making cluster, finds that only 0.5 per cent of small scale enterprises have a production link with the formal sector without being dependent on large enterprises, while the large majority face production linkages in which they have a very weak bargaining position. Uchikawa (2011) finds that the portion of informal enterprises that engages in subcontracting with multinationals in India's machinery industry is relatively small, due to the inability of most informal enterprises to meet the minimum conditions imposed by formal enterprises. Sahu (2010) surveys 400 informal manufacturing enterprises and shows that almost half of the subcontracting units produce with technology prescribed by the parent enterprise and 16 per cent has difficulties with stringent quality control. 
Regarding the subcontracting activities of formal enterprises, the only available empirical evidence representative of all-India manufacturing is a study by Ramaswamy (1999). He documents an increase in subcontracting intensity of formal sector production between 1970 and the early 1990s. In 1992-93, subcontracting was used most in laborintensive industries and in industries with the highest average employment per factory. A complete and more up to date picture of formal-informal production links in Indian manufacturing is currently lacking, and it therefore remains unclear how formal sector subcontracting is related to the evolution of the informal sector as a whole.

\section{Data sources and empirical approach}

\subsection{Data sources}

The empirical analysis in this paper is based on nationally representative survey data for Indian manufacturing enterprises. Data on the formal sector are obtained from the Annual Survey of Industries (ASI) for the years 1994-95, 2000-01 and 2005-06, which cover all registered manufacturing establishments. Data on the informal sector are obtained from the National Sample Survey (NSS) of unorganized manufacturing for the same years. The NSS survey covers all unregistered manufacturing establishments including home-based enterprises without any workers other than the owner. All unit level data are aggregated to the state-industry level, with industries defined at the 2-digit level of the National Industrial Classification, as listed in Table A.1 in Appendix A. In the empirical analysis the focus is on India's 16 major states and the National Capital Territory of Delhi, resulting in an unbalanced panel of up to 20 industries in 17 states in 1994-95, 2000-01, and 2005-06. A description of the informal sector and formal sector subcontracting is provided in section 4 , after the empirical model and measurement of variables are explained.

\subsection{Empirical model}

A panel fixed effects model is estimated to test whether formal sector subcontracting is related to expansion of the informal sector. Given the contrast between the stagnation view and modernization view described above, the key question is whether this relationship depends on the degree of modernity of the informal sector.

In this section, two empirical models are specified, both with an indicator of informal sector size as the dependent variable and formal sector subcontracting and informal sector modernity as the key independent variables. In the first specification, a continuous 
measure of modernity for state-industries is used, such that the degree of informal sector modernity moderates the relationship between formal sector subcontracting and informal sector outcome:

$$
\ln \left(Y_{i s t}\right)=\alpha_{\mathrm{is}}+\beta_{1} \ln (F S)_{i s t}+\beta_{2} M_{i s t}+\beta_{3} \ln (F S)_{i s t} * M_{i s t}+\pi_{\mathrm{st}}+\mu_{\mathrm{it}}+\varepsilon_{\mathrm{ist}}
$$

where the dependent variable is a measure of informal sector size in industry $i$ and state $s$, in year $t$. The $\alpha_{i s}$ are state-industry fixed effects that capture any time-invariant unobserved heterogeneity related to the outcome variable, $\ln (F S)_{\text {ist }}$ is the $\log$ real value of formal sector subcontracting and $\beta_{1}$ is the main effect of formal sector subcontracting on the informal sector size. $M_{i s t}$ is an index of the degree of modernity of the informal sector, which has a main effect $\beta_{2}$. The estimate of $\beta_{2}$ will indicate whether, all else equal, the more modern state-industries are larger than the more traditional state-industries in India’s informal manufacturing sector.

To test for the two aforementioned contrasting perspectives, formal subcontracting is interacted with the informal sector modernity index, and this interaction effect is captured by the estimate of $\beta_{3}$. Given that a higher value of the modernity index indicates more modern informal production, a positive estimate of $\beta_{3}$ would mean that formal sector subcontracting is associated with expansion in the relatively modern informal sector segment, or at least more so than with expansion the relatively traditional segment. A negative estimate of $\beta_{3}$ would indicate the opposite. Therefore, a positive estimate would support the modernization view, whereas a negative estimate would support the stagnation view.

Even in the fixed effects specification, one may be concerned that the within-stateindustry variation of informal sector size and formal sector subcontracting are jointly determined by unobserved factors. To address this omitted variables concern, state-time $\left(\pi_{\mathrm{st}}\right)$ dummies are added to capture unobserved determinants that are common to all industries in a given state, such as different rates of population or economic growth across states. Additionally, industry-time $\left(\mu_{\mathrm{it}}\right)$ dummies are added to capture unobserved determinants common to all states for a given industry, such as different rates of technological change across industries. The last term $\varepsilon_{i s t}$ is a stochastic error term.

In equation (1), the relationship between subcontracting and informal sector size is allowed to change linearly in the degree of informal sector modernity. There may, however, be discontinuities along the distribution: it could be the case that only the most modern segment of the informal sector expands with formal sector subcontracting or even that both views of subcontracting apply, in which case subcontracting is related to 
informal sector expansion at both extremes of the modernity distribution. To allow more flexibility in the effect of subcontracting, an alternative model is specified where the effect of formal subcontracting is estimated at each quartile of the modernity distribution:

$$
\ln \left(Y_{i s t}\right)=\alpha_{\text {is }}+\sum_{\mathrm{r}=1}^{4} \gamma_{1 \mathrm{r}} \ln (F S)_{\text {ist }} * M q_{\mathrm{ist}}^{\mathrm{r}}+\sum_{\mathrm{r}=2}^{4} \gamma_{2 \mathrm{r}} M q_{\mathrm{ist}}^{\mathrm{r}}+\pi_{\mathrm{st}}+\mu_{\mathrm{it}}+\varepsilon_{\text {ist }}
$$

Where $M q_{\text {ist }}^{\mathrm{r}}$ is an indicator variable equal to one if the modernity index of the stateindustry in year $t$ falls into quartile $r(=1,2,3,4)$ of the modernity distribution.

A remaining potential source of bias in the estimated effects of formal sector subcontracting is reverse causality: it may be the case that formal enterprises increase their subcontracting activities in response to an expanding informal sector. One would have to find an exogenous source of variation in formal sector outsourcing that is not directly related to informal sector outcomes, to get an unbiased estimate of the causal effect. For lack of such an instrument, the estimates cannot be interpreted strictly as causal effects. Even though reverse causality may drive part of the estimated effects, they still show which segment(s) of the informal sector are complementary to the formal sector through subcontracting linkages.

\subsection{Measurement of variables}

Four different outcome variables are considered to measure informal sector size. These are total state-industry employment, number of hired workers, number of enterprises, and the total real wage bill. The wage bill recorded in the data refers to total emoluments paid to hired workers and, as such, does not include information of monetary payments or other types of compensation to non-hired (family) workers. The real wage bill is obtained by deflating the nominal wage bill using state- and industry-specific wholesale price indices. Informal sector aggregates are adjusted using the published National Accounts data for GDP in unregistered manufacturing following the procedure described in Appendix B. Results are reported based on the adjusted aggregates, but the unadjusted survey-based aggregates give very similar results.

Formal sector subcontracting, $F S_{i s t}$, is measured as the sum of the purchase value of goods sold in the same condition as purchased, and the cost of contract and commission work done by others on materials supplied by the factory. ${ }^{4}$ Both are available at the enterprise level in the ASI data and aggregated by state-industry. The total subcontracting

\footnotetext{
${ }^{4}$ In a similar way, Ramaswamy (1999) measures subcontracting intensity in formal manufacturing. His measure, which is the ratio of the value of goods sold in the same condition as purchased to value added, excludes other forms of subcontracting recorded as contract work performed on materials supplied.
} 
value is deflated in the same way as informal wages. It is important to note that it is not possible to distinguish the proportion of subcontracting undertaken by informal enterprises in the data: The total value of subcontracting consists of all subcontracting from the formal sector and is an indicator of the size of subcontracting in a given industry, whether it is being subcontracted to another formal sector or to the informal sector.

A central element of the analysis of this paper is the measure of modernity of the informal sector. In the framework of Ranis and Stewart (1999), the modern informal segment is characterized by significant capital per worker, the use of skills and hired labor, and enterprises located outside their owners' homes. They describe certain industries, such as metalworking, as typically modern and others, such as textile handlooms, as typically traditional. In the model of Marjit (2003), the capital-intensive segment of the informal sector produces an intermediate used by the formal sector, so it is the capital-intensive segment that expands with formal sector subcontracting.

In this paper, the degree of modernity for each state-industry is measured in each year based on the location of informal enterprises, defined as the log ratio of the number of enterprises with a fixed location outside of the household to the number of enterprises located inside the household or without a fixed location:

$$
\text { Out_In } n_{\text {ist }}=\ln \left(N_{-} o u t_{i s t} /\left(N_{\text {ist }}-N_{-} \text {out } t_{\text {ist }}\right)\right) \text {. }
$$

That is, an enterprise with a fixed location outside the household premises is considered a modern enterprise, and the modernity of a state-industry is measured as the log ratio of modern enterprises relative to traditional enterprises. For the empirical estimations, this value is standardized to have a mean zero and a standard deviation of one. Ranis and Stewart (1999) seem to suggest a dichotomous classification of industries into the modern or traditional segment of the informal sector. The modernity measure in this paper, on the other hand, is continuous and thus allows for different degrees of modernity across stateindustries. The measure based on enterprise location captures several dimensions of modernity: more modern state-industries have, on average, more workers and more hired workers per enterprise, more assets (owned and hired fixed capital) per enterprise, and higher annual value added per enterprise than traditional state-industries (see Table A.2 in Appendix A).

In this study, the location-based measure is preferred to other proxies for modernity. The main reason is that the location of enterprises in a given state-industry provides a 
more consistent measure of modernity than other measures such as the capital-labor ratio or wages. It is subject to less measurement error, but is also more consistent as location itself is less likely to change over time due to production linkages with the formal sector. Furthermore, home-based labor in India is often associated with traditional informal activities in the literature, and the location measure should also capture the incidence of home-based labor in state-industries (Carr et al., 2000; Rani and Unni, 2011). ${ }^{5}$

\section{Informal employment, informal sector modernity, and subcontracting trends}

Before turning to the estimation results, this section describes the growth and modernity of the informal sector and trends in formal sector subcontracting. Table A.3 in Appendix A shows summary statistics of all variables, indicating a steady increase in subcontracting by formal enterprises and in informal sector employment between 1994-95 and 2005-06.

\subsection{Modernity and employment in the informal sector across industries and states}

For each state-industry in each year, the modernity index is measured as the standardized value of equation (3). Figure 2 shows the distribution of informal sector employment across modernity quartiles for the different years. In 2005-06 less than ten percent of total informal employment is in state-industries in the top quartile of the modernity index distribution (those where the majority of enterprises has a fixed location outside the household). Thus, the largest share of informal manufacturing employment remains in the most traditional activities over the analyzed period of ten years. Apart from the second quartile growing relative to the first, there is no clear sign of informal sector modernization between 1994-95 and 2005-06.

Figure A.1 in Appendix A shows the distribution of informal sector employment across 2-digit industries, for all-India, in the three survey years. Most informal sector employment is in food and beverages (industry code 15) and textiles (17), followed by wearing apparel (18), tobacco (16), and wood (20). Between 1994-95 and 2005-06 employment growth was concentrated especially in tobacco and wearing apparel,

\footnotetext{
${ }^{5}$ According to ILO (2002), approximately 14 per cent of non-agricultural employment in India corresponds to informal wage employment outside informal enterprises, that is, informal workers directly contracted by formal enterprises. For this reason a complete measure of home-based labor would have to be made on a worker basis, but for the case of India an enterprise-based measure captures the incidence of home-base labor to a large extent.
} 
followed by the chemicals and chemical products industry (24), and fabricated metal products (28).

Figure 2: Informal sector employment by modernity quartile

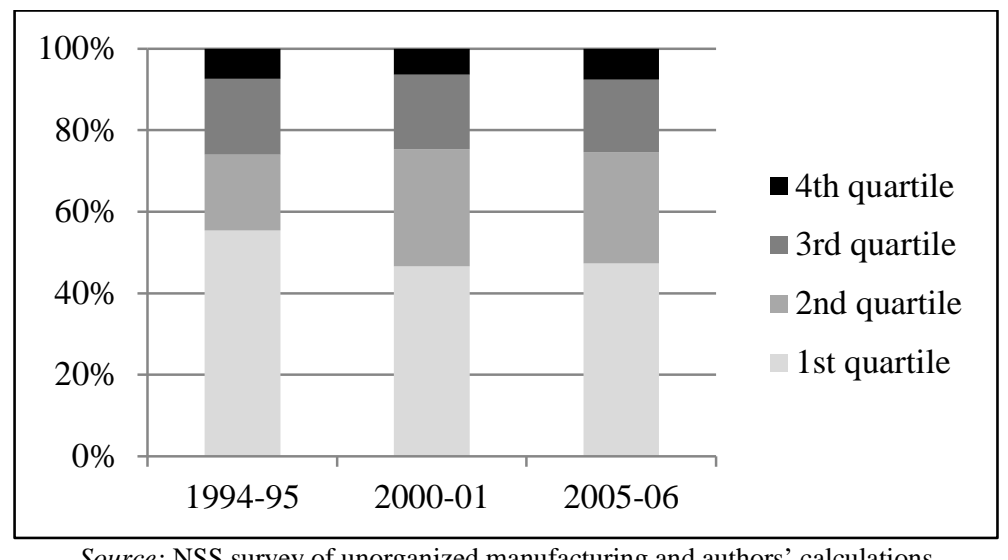

The non-standardized modernity values by industry, again for all-India, are summarized in Figure A.2 in Appendix A. Industries with the highest share of enterprises located outside the household are motor vehicles (34); medical, precision, and optical instruments (33); electrical machinery (31); and publishing and printing (22). Tobacco production is the most traditional informal sector industry in India, with the largest share of home-based enterprises. This sector uses very few capital assets and almost no hired workers. This might be due to the large segment of bidi-rolling ${ }^{6}$ in this sector, which is largely a home-based activity, undertaken mainly by women. Wearing apparel and chemical products are also rather traditional activities in the informal sector (the latter consists mainly of the production of incense and matches), whereas fabricated metal production is a relatively modern informal activity, with about, on average, half the enterprises home-based and almost one hired worker per enterprise.

Besides variation across industries, there is also considerable spatial variation in the degree of modernity of the informal sector. Panel a) in Figure 3 displays the share of informal manufacturing employment in relatively modern industries (i.e., those with above-average modernity) by state in 2005-06, which varies from 1.33 per cent in the north-eastern state of Bihar to 81.54 per cent in the national capital Delhi. In general, highly industrialized states such as Maharashtra and Gujarat and states with larger share of educated work force such as Kerala seem to have a larger share of relatively modern

\footnotetext{
${ }^{6}$ Bidi is a thin Indian cigarette filled with tobacco flake and wrapped in dry leaf which outsells cigarettes in India.
} 
informal employment. Panel b) shows the change in this share between 1995 and 2005, indicating there are no clear convergence or divergence trends across states: while some states such as Orissa with small (high) initial shares of informal manufacturing employment in modern industries experienced an increase in this share, others such as Bihar have actually experienced a reduction. Likewise, there is no clear growth pattern among states with above average shares of informal manufacturing employment in modern industries relative to total informal manufacturing employment.

Figure 3: Employment in modern informal manufacturing

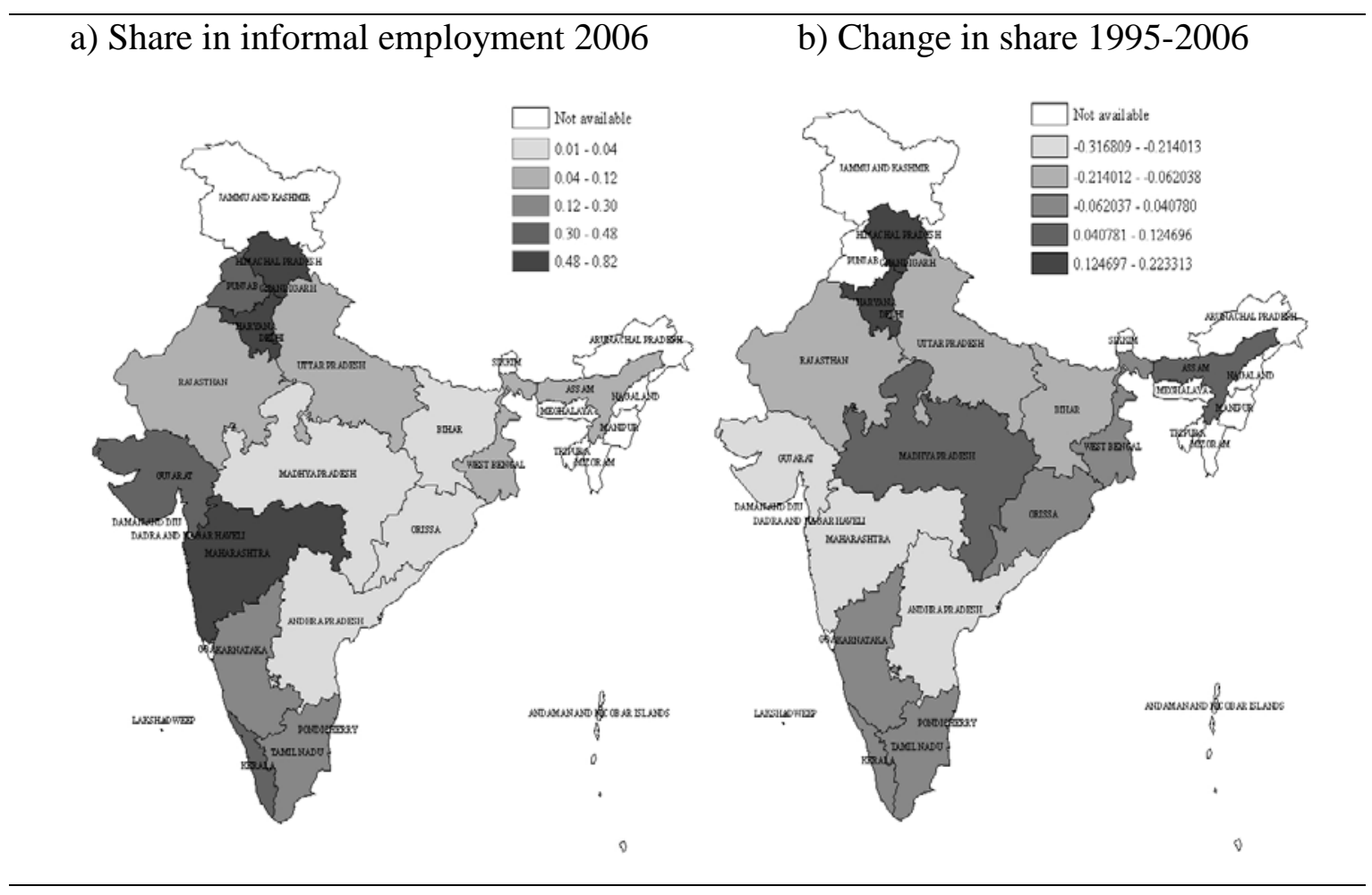

\subsection{Formal sector subcontracting}

Figure 4 shows the trend in subcontracting in the formal manufacturing sector as a whole. The subcontracting intensity, measured as a percentage of output, increased sharply in the late 1990s and, although declining somewhat after 1999, remains much higher than in the early 1990s. 
Figure 4: Formal sector subcontracting intensity (ratio of subcontracting to output)

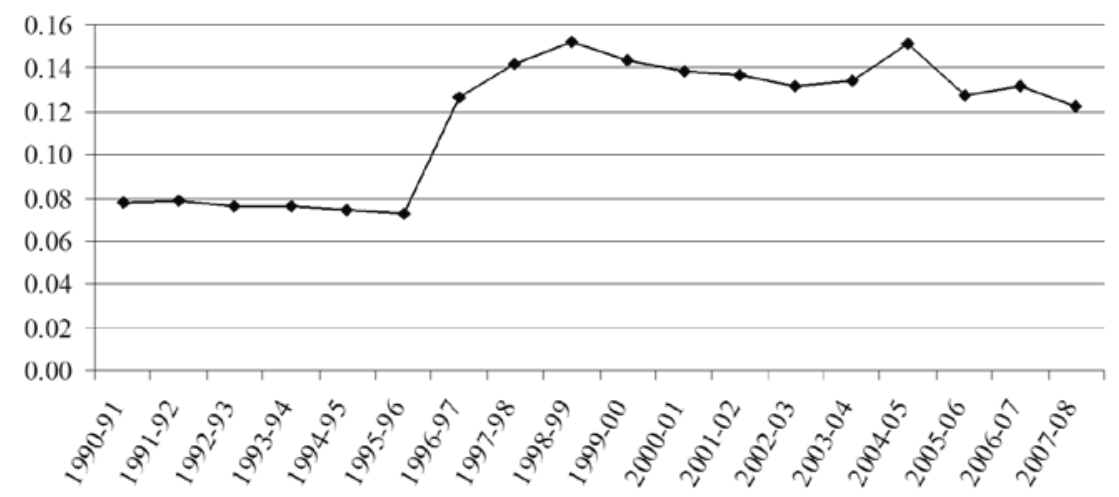

Source: Annual Survey of Industries

Figures A.3 in Appendix A shows the subcontracting intensity in two-digit manufacturing sectors over time. Subcontracting intensity has increased in all industries except in paper and paper products (21), and most of the increase was concentrated in the first period, between 1995 and 2001. The increase over the whole period was largest in wood manufacturing (20). The wearing apparel industry (18), which is highly labor intensive, is the most subcontracting-intensive sector. However, there has been a decline in the correlation between subcontracting intensity and labor intensity (measured as employment per fixed capital) from 0.42 in 1995 to 0.28 in 2006. Clearly, some of the capital-intensive industries such as medical and optical instruments (code 33) are also rather subcontracting-intensive. The real value of subcontracting has increased over the years in all the two-digit industries (not shown), with industries office machinery and communication equipment, furniture, wood, and food products showing the fastest growth.

Figure 5: Formal sector subcontracting by modernity quartile

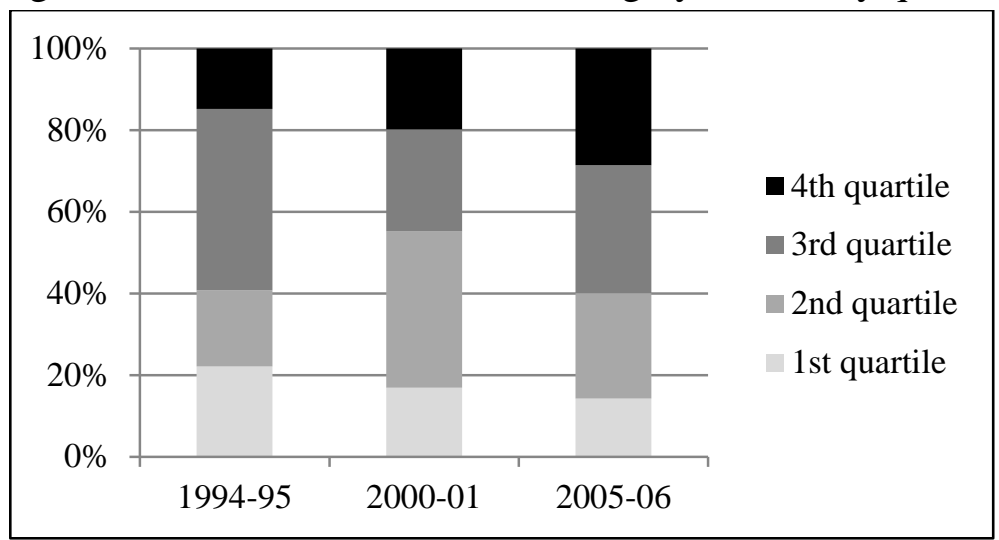

Source: Annual Survey of Industries, NSS survey of unorganized manufacturing and authors calculations. 
Figure 5 shows how the total value of formal sector subcontracting is distributed across the four informal sector segments (the four quartiles of the modernity index distribution). It clearly shows that formal sector subcontracting grew faster in stateindustries where the informal sector is most modern, whereas the share of total formal manufacturing subcontracting in state-industries with very traditional informal sectors declined.

\section{Results}

\subsection{Main results}

Equation (1) is estimated using a panel fixed effect estimator. Table 1 shows the estimation results for different dependent variables (employment, hired workers, number of enterprises and wage bill), also controlling for industry-year and state-year effects.

Table 1: Estimation results continuous specification

\begin{tabular}{|c|c|c|c|c|}
\hline Dependent variable (in logs): & $\begin{array}{c}(1) \\
\text { Employment }\end{array}$ & $\begin{array}{c}(2) \\
\text { Hired workers } \\
\end{array}$ & $\begin{array}{c}\text { (3) } \\
\text { \# of enterprises }\end{array}$ & $\begin{array}{c}(4) \\
\text { Wage bill }\end{array}$ \\
\hline $\ln (F S)$ & $\begin{array}{l}0.072 * \\
(0.040)\end{array}$ & $\begin{array}{c}0.036 \\
(0.056)\end{array}$ & $\begin{array}{c}0.051 \\
(0.038)\end{array}$ & $\begin{array}{c}0.020 \\
(0.063)\end{array}$ \\
\hline$M$ & $\begin{array}{c}-1.610^{* * *} \\
(0.400)\end{array}$ & $\begin{array}{c}-1.140 * * \\
(0.560)\end{array}$ & $\begin{array}{c}-1.300 * * * \\
(0.450)\end{array}$ & $\begin{array}{l}-1.020 \\
(0.650)\end{array}$ \\
\hline $\ln (F S) * M$ & $\begin{array}{c}0.077 * * * \\
(0.020)\end{array}$ & $\begin{array}{c}0.066^{* *} \\
(0.027)\end{array}$ & $\begin{array}{l}0.057 * * \\
(0.022)\end{array}$ & $\begin{array}{l}0.061 * * \\
(0.031)\end{array}$ \\
\hline Constant & $\begin{array}{c}9.298^{* * * *} \\
(0.789)\end{array}$ & $\begin{array}{c}8.637 * * * \\
(1.116)\end{array}$ & $\begin{array}{c}7.828^{* * *} \\
(0.763)\end{array}$ & $\begin{array}{c}18.52^{* * *} \\
(1.257)\end{array}$ \\
\hline $\mathrm{N}$ & 877 & 876 & 877 & 876 \\
\hline R-squared & 0.53 & 0.42 & 0.58 & 0.49 \\
\hline State-Year FE & Yes & Yes & Yes & Yes \\
\hline Industry-year FE & Yes & Yes & Yes & Yes \\
\hline
\end{tabular}

For all four informal sector outcomes the main effect of formal sector subcontracting is insignificant at the $95 \%$ level of confidence. There is, however, a significantly positive effect of formal sector subcontracting when interacted with the modernity index. This positive relation between subcontracting and informal sector size in the more modern informal sector gives support for the existence of a complementary production link between modern informal and formal manufacturing. Through this link, formal sector 
subcontracting growth is related to expansion of the relatively modern segment in informal manufacturing.

The modernity index has a negative sign, which is significant in all models except in the last model, where the dependent variable is wage bill. This negative sign of the modernity index is indicative of a larger informal sector in more traditional activities, as was seen in Figure 2, or faster growth in state-industries that are becoming more traditional. This could be capturing the fact that, all else equal, most informal sector expansion is taking place in home-based enterprises so expansion is associated with a decline in the modernity index.

Figure 6: Marginal effect of formal sector subcontracting on informal sector outcomes

a) Employment

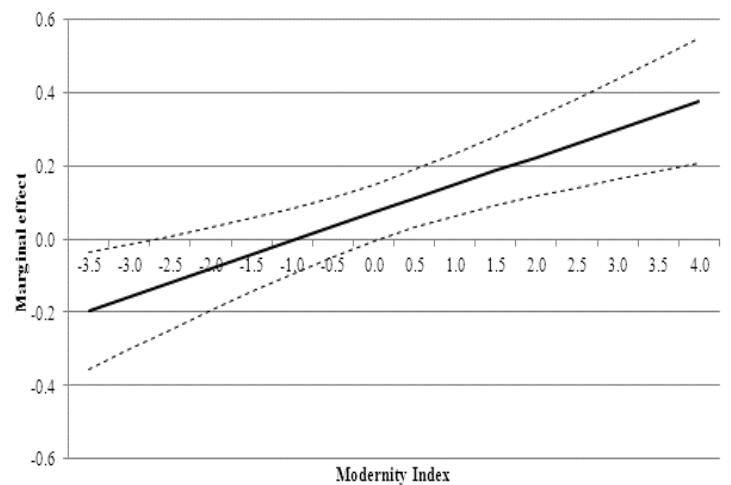

c) Enterprises

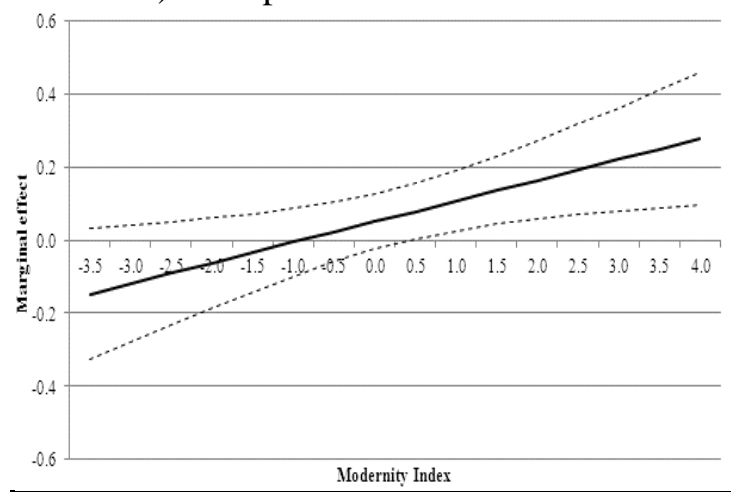

b) Hired workers

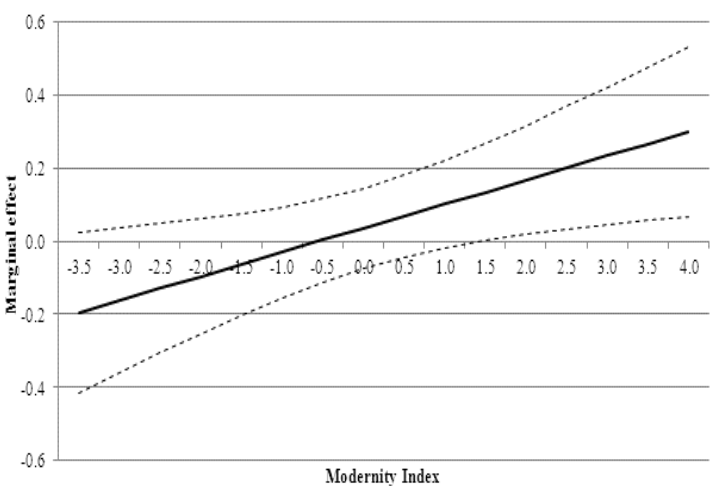

d) Wage bill

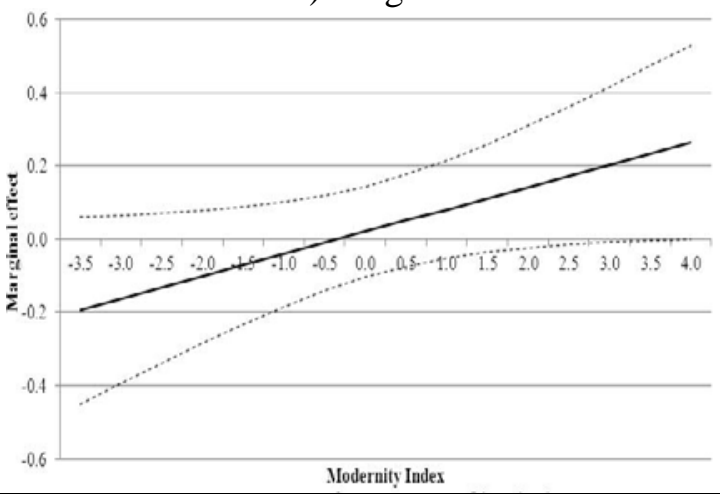

Note: Solid line shows the estimated marginal effect, dashed lines show the 95 per cent confidence interval. Horizontal axis measures the standardized modernity value.

Figure 6 plots the marginal effect of formal sector subcontracting on informal sector outcomes for the entire range of values of the modernity index. It is calculated as $\hat{\beta}_{1}+\hat{\beta}_{3} \times M$ with the coefficient estimates in the respective column of Table 1 and the corresponding estimated variance-covariance matrices. For informal sector employment 
and number of enterprises, the marginal effect is significantly positive for roughly the top half of the modernity index distribution. The effect on employment is largest, and shows that for state-industries with a modernity index one standard deviation above average, an increase in the log value of formal sector subcontracting by 0.5 (the average increase over 5 years) is associated with an increase in informal employment by 8 percent, or about one third of the average 5-year increase in informal employment. For hired workers, the effect is significantly positive only for state-industries with modernity index above 1.5, while the effect on the wage bill is somewhat lower and not significantly different from zero at any point.

Table 2: Estimation results quartiles specification

\begin{tabular}{|c|c|c|c|c|}
\hline Dependent variable (in logs): & $\begin{array}{c}\text { (1) } \\
\text { Employment }\end{array}$ & $\begin{array}{c}(2) \\
\text { Hired workers }\end{array}$ & $\begin{array}{c}\text { (3) } \\
\text { \# of enterprises }\end{array}$ & $\begin{array}{c}\text { (4) } \\
\text { Wage bill }\end{array}$ \\
\hline $\ln (F S) * M q^{1}$ & $\begin{array}{l}-0.022 \\
(0.056)\end{array}$ & $\begin{array}{l}-0.063 \\
(0.070)\end{array}$ & $\begin{array}{l}-0.029 \\
(0.055)\end{array}$ & $\begin{array}{l}-0.055 \\
(0.087)\end{array}$ \\
\hline $\ln (F S) * M q^{2}$ & $\begin{array}{c}0.049 \\
(0.049)\end{array}$ & $\begin{array}{c}0.003 \\
(0.067)\end{array}$ & $\begin{array}{c}0.032 \\
(0.048)\end{array}$ & $\begin{array}{l}-0.012 \\
(0.074)\end{array}$ \\
\hline $\ln (F S) * M q^{3}$ & $\begin{array}{c}0.128 * * * \\
(0.048)\end{array}$ & $\begin{array}{c}0.043 \\
(0.079)\end{array}$ & $\begin{array}{l}0.115^{* *} \\
(0.048)\end{array}$ & $\begin{array}{c}0.042 \\
(0.085)\end{array}$ \\
\hline $\ln (F S) * M q^{4}$ & $\begin{array}{c}0.166^{* * *} \\
(0.044)\end{array}$ & $\begin{array}{l}0.149 * * \\
(0.056)\end{array}$ & $\begin{array}{c}0.125^{* * *} \\
(0.042)\end{array}$ & $\begin{array}{l}0.117 * \\
(0.068)\end{array}$ \\
\hline$M q^{2}$ & $\begin{array}{l}-1.472 \\
(0.913)\end{array}$ & $\begin{array}{l}-1.044 \\
(1.159)\end{array}$ & $\begin{array}{l}-1.371 \\
(0.938)\end{array}$ & $\begin{array}{l}-0.619 \\
(1.403)\end{array}$ \\
\hline$M q^{3}$ & $\begin{array}{c}-3.182 * * * \\
(1.003)\end{array}$ & $\begin{array}{l}-1.694 \\
(1.513)\end{array}$ & $\begin{array}{c}-3.267 * * * \\
(1.045)\end{array}$ & $\begin{array}{l}-1.579 \\
(1.743)\end{array}$ \\
\hline$M q^{4}$ & $\begin{array}{c}-3.788 * * * \\
(1.018)\end{array}$ & $\begin{array}{c}-3.698 * * * \\
(1.424)\end{array}$ & $\begin{array}{c}-3.319 * * * \\
(1.106)\end{array}$ & $\begin{array}{l}-2.901 \\
(1.863)\end{array}$ \\
\hline Constant & $\begin{array}{c}11.23^{* * *} \\
(1.119)\end{array}$ & $\begin{array}{c}10.31^{* * *} \\
(1.414)\end{array}$ & $\begin{array}{c}9.606^{* * *} \\
(1.101)\end{array}$ & $\begin{array}{c}19.74 * * * \\
(1.785)\end{array}$ \\
\hline $\mathrm{N}$ & 877 & 876 & 877 & 876 \\
\hline R-squared & 0.53 & 0.43 & 0.58 & 0.50 \\
\hline State-Year FE & Yes & Yes & Yes & Yes \\
\hline Industry-year FE & Yes & Yes & Yes & Yes \\
\hline
\end{tabular}

Table 2 shows the estimation results for equation (2), which is also estimated using a panel fixed effect estimator, and controls for industry-year and state-year effects. The results of the quartiles specification broadly support the previous findings. The interaction term is positive, significant and statistically equivalent for the third and fourth quartiles when using employment and number of enterprises as dependent variables. It is significant only for the fourth quartile for the number of hired workers and wage bill. 
Everything else equal, a 0.5 increase in the log value of formal sector subcontracting (the average 5-year increase in the sample) is associated with an increase of 8.3 per cent in employment, 7.5 per cent in the number of hired workers, 6.3 per cent in the number of enterprises, 5.9 per cent in the total wage bill in the most modern $\left(4^{\text {th }}\right.$ quartile) informal activities, and a 6.4 per cent and 5.8 per cent increase in employment and number of enterprises in the more modern segment ( $3^{\text {rd }}$ quartile). According to the results, no association is found between outcomes in the traditional segments of the informal sector and formal subcontracting.

\subsection{Robustness checks}

As described in Appendix B, the informal sector size measures have been adjusted to National Accounts aggregates for informal manufacturing. The results are very similar when using unadjusted survey aggregates, but for the sake of space, are not presented here.

Second, the results are also robust to the inclusion of the size of the formal sector as an additional control variable. According to Ranis and Stewart (1999), informal sector size is affected by the rate of growth of formal non-agricultural employment and output. ${ }^{7}$ In the context of the Harris-Todaro model, formal sector employment growth serves as a signal for formal sector employment opportunities which causes an excessive movement of workers towards that sector and a consequent increase in the size of the informal sector. In the estimation proposed in this paper, given that the unit of analysis is the stateindustry, it is not possible to include formal sector employment growth at large.

Still, as a robustness check, formal sector employment at the state-industry level can be included as a control variable when informal sector employment is the dependent variable. Including formal employment also serves as a control for the independent effect of subcontracting on informal sector outcomes. Indeed, if the significance of the relationship found in the previous section relies solely on a third-variable driving growth in the formal and informal sectors in each state-industry, the significance of the subcontracting variable could be undermined by the inclusion of formal sector employment. Because this reasoning applies for the other informal sector outcomes as well, the same robustness check is also applied for number of enterprises and wage bill. ${ }^{8}$

\footnotetext{
${ }^{7}$ Other determinants include population and technology (Ranis and Steward, 1999, p. 263), which should be captured by state-time and industry-time effects.

${ }^{8}$ Information for number of hired workers for the formal sector is not available for all periods.
} 
Table 3 presents the results. The inclusion of the additional variables tends to increase the estimated effects of subcontracting somewhat, both for the continuous specifications (columns 1-3) and the quartiles specifications (columns 4-6). Formal sector outcomes do not seem to have an independent effect on informal sector outcomes, while for informal sector employment and number of enterprises, the positive coefficient on subcontracting in the top two quartiles remains highly significant.

Table 3: Estimation results including additional control variable

\begin{tabular}{|c|c|c|c|c|c|c|}
\hline & (1) & (2) & (3) & (4) & (5) & (6) \\
\hline $\begin{array}{l}\text { Dependent } \\
\text { variable (logs): }\end{array}$ & Employment & $\begin{array}{c}\text { \# of } \\
\text { enterprises }\end{array}$ & Wage bill & Employment & $\begin{array}{c}\text { \# of } \\
\text { enterprises }\end{array}$ & Wage bill \\
\hline \multirow[t]{2}{*}{$\ln (F S) * M$} & $0.078 * * *$ & $0.058 * *$ & $0.064 * *$ & & & \\
\hline & $(-0.020)$ & $(-0.023)$ & $(0.031)$ & & & \\
\hline \multirow[t]{2}{*}{$\ln (F S)$} & $0.109 *$ & 0.066 & 0.054 & & & \\
\hline & $(-0.058)$ & $(-0.046)$ & $(0.090)$ & & & \\
\hline \multirow[t]{2}{*}{$M$} & $-1.646 * * *$ & $-1.311 * * *$ & -1.062 & & & \\
\hline & $(-0.410)$ & $(-0.456)$ & $(0.658)$ & & & \\
\hline \multirow[t]{2}{*}{$\ln (F S) * M q^{1}$} & & & & 0.006 & -0.012 & -0.028 \\
\hline & & & & $(-0.068)$ & $(-0.061)$ & $(0.101)$ \\
\hline \multirow[t]{2}{*}{$\ln (F S) * M q^{2}$} & & & & 0.081 & 0.051 & 0.019 \\
\hline & & & & $(-0.067)$ & $(-0.057)$ & $(0.097)$ \\
\hline \multirow[t]{2}{*}{$\ln (F S) * M q^{3}$} & & & & $0.160 * * *$ & $0.134^{* *}$ & 0.074 \\
\hline & & & & $(-0.062)$ & $(-0.055)$ & $(0.109)$ \\
\hline \multirow[t]{2}{*}{$\ln (F S) * M q^{4}$} & & & & $0.199 * * *$ & $0.143^{* * *}$ & 0.149 \\
\hline & & & & $(-0.062)$ & $(-0.05)$ & $(0.096)$ \\
\hline \multicolumn{7}{|c|}{ Formal sector control variables: } \\
\hline \multirow[t]{2}{*}{ In(employment) } & -0.082 & & & -0.069 & & \\
\hline & $(-0.080)$ & & & $(-0.082)$ & & \\
\hline \multirow[t]{2}{*}{ In(\# enterprises) } & & -0.071 & & & -0.083 & \\
\hline & & $(-0.095)$ & & & $(-0.102)$ & \\
\hline \multirow[t]{2}{*}{ ln(wage bill) } & & & -0.065 & & & -0.059 \\
\hline & & & $(0.102)$ & & & $(0.101)$ \\
\hline $\mathrm{N}$ & 876 & 877 & 875 & 876 & 877 & 875 \\
\hline R-squared & 0.53 & 0.58 & 0.49 & 0.53 & 0.58 & 0.50 \\
\hline State-Yr FE & Yes & Yes & Yes & Yes & Yes & Yes \\
\hline Industry-Yr FE & Yes & Yes & Yes & Yes & Yes & Yes \\
\hline
\end{tabular}

Note: The constant term and main effects of modernity quartiles are not reported but are included in the estimations. Clustered standard errors are reported in parentheses below the point estimates; * significant at the .10 level; ** at the .05 level; *** at the .01 level. 


\section{Discussion and conclusions}

An important channel through which formal enterprises interact with informal enterprises is via subcontracting a part of their production process. However, little is known about how this subcontracting affects the evolution of the informal sector, which accounts for a major portion of employment in developing countries. This paper analyzes the role of formal sector subcontracting in the evolution of the informal sector, contrasting between two existing views of formal-informal production linkages. One view argues that subcontracting contributes to informal sector stagnation (e.g., Portes, 1994), while the other view holds that subcontracting stimulates modernization of the informal sector (Marjit, 2003; Ranis and Stewart, 1999).

The empirical analysis uses representative data for formal and informal enterprises in Indian manufacturing in 1994-95, 2000-01, and 2005-06, asking whether subcontracting is related to expansion of traditional or modern segments of the informal sector. The Indian economy has witnessed rapid economic growth since the onset of liberalization policies in the early 1990s. During this period, formal enterprises have increasingly subcontracted part of their production process. At the same time, employment in informal manufacturing grew substantially, remaining at almost 90 per cent of total manufacturing employment.

Modernity of the informal sector is measured at the state-industry level, as the share of enterprises located outside the household premises. This measure is highly correlated with other dimensions of modernity such as number of (hired) workers, fixed assets, and value added per enterprise. Though in absolute terms, informal manufacturing growth was concentrated in the most traditional activities, no evidence is found that this was driven by growth of formal sector subcontracting. On the contrary, relying on within state-industry variation and controlling for further unobserved heterogeneity, a significant positive relationship is found between formal sector subcontracting and total employment or number of enterprises in the relatively modern segments of the informal sector. The results support the modernization view of formal-informal production linkages whereby formal enterprises subcontract to the more modern rather than traditional informal sector enterprises based on quality and reliability considerations. Through its complementarity with the modern informal sector segment, formal sector subcontracting is associated with modernization of the informal sector.

Despite this complementarity, subcontracting has not played a major role in the evolution of the informal manufacturing sector, as informal employment remains largely 
concentrated in relatively traditional activities. The results of this paper suggest that policies could focus on subcontracting to stimulate modernization of informal manufacturing, but to know exactly what types of policies would work it continues to be important knowing how formal-informal production links affect the performance of the individual enterprise. For lack of longitudinal enterprise-level data, such empirical evidence is currently not available, but future work in this area can complement the results of this paper.

The fast growth of traditional informal manufacturing in India, which is found to be unrelated to formal sector subcontracting, may be explained from the perspective of structural change and industrial growth. With industrial development, formal enterprises tend to exit highly competitive, labor-intensive industries and enter more capital-intensive industries with higher barriers to entry. As part of this process, traditional informal enterprises may take over the low-end markets, which would explain the expansion of the traditional informal activities, but this expansion would not be caused by formal-informal production linkages. Alternatively, there is some evidence that India's strict labor regulation plays a role in this process of shifting production from the formal to the informal sector: Besley and Burgess (2004) show that pro-worker amendments to labor laws reduce formal manufacturing output and employment, while increasing in the size of informal manufacturing. Also indicative is the work of Aghion et al. (2008), who analyze the effects of industrial delicensing on formal manufacturing. This reform had a greater effect of formal sector output growth in states with pro-employer labor regulation than in states with pro-worker labor regulation. Although neither study accounts for the modernity or labor-intensity of production, in light of the findings of this paper they suggest that persistent informality in traditional and most labor-intensive manufacturing may be related more to regulation constraining the formal sector than to structural production links between formal and informal enterprises. 


\section{References}

Aghion, P., R. Burgess, S. Redding, and F. Zilibotti (2008), The Unequal Effects of Liberalization: Evidence from Dismantling the License Raj in India. American Economic Review, 98(4): 1397-1412

Arimah, B. C. (2001) Nature and Determinants of the Linkages between Informal and Formal Sector Enterprises in Nigeria. African Development Review, 13(1): 114-144

Besley, T. and R. Burgess (2004), Can Labor Regulation Hinder Economic Performance? Evidence from India. The Quarterly Journal of Economics, 119(1): 91-134

Boehme, M. and R. Thiele (2012), Informal-formal Linkages and Informal Enterprise Performance in Urban West Africa. Kiel Working Papers 1751, Kiel Institute for the World Economy

Carr, M., M. A. Chen, and J. Tate (2000), Globalization and Home-Based Workers. Feminist Economics, 6(3): 123-142

Davies, R. and J. Thurlow (2010), Formal-informal economy linkages and unemployment in South-Africa, South African Journal of Economics, 78(4): 437-459

De Vries, G., A. A. Erumban, M. P. Timmer, I. Voskoboynikov, and H. Wu (2012), "Deconstructing the BRICs: Structural Transformation and Aggregate Productivity Growth", Journal of Comparative Economics, 40(2): 211-227

Fields, G. (2005), A guide to multisector labor market models. Social Protection Discussion Paper Series 0505, World Bank.

Ghani, E., W. R. Kerr, and S. D. O’Connell (2011), Spatial Determinants of Entrepreneurship in India. NBER Working Paper W17514, NBER

Gunther, I. and A. Launov (2011), Informal employment in developing countries. Opportunity or last resort? Journal of Development Economics, 97(1): 88-98

Hart, K. (1973), Informal Income Opportunities and Urban Employment in Ghana. The Journal of Modern African Studies, 11(1): 61-89

House, W. J. (1984), Nairobi's Informal Sector: Dynamic Entrepreneurs or Surplus Labor? Economic Development and Cultural Change, 32(2): 277-302

ILO (2002), Women and men in the informal economy: a statistical picture. Geneva: International Labor Organization

ILO and WTO (2009), Globalization and informal jobs in developing countries. Geneva: ILO and WTO

Knorringa, P. (1994), Lack of interaction between traders and producers in the Agra footwear cluster. In: Pedersen, P.O., Sverisson, A. and van Dijk M.P. (eds.) Flexible 
Specialization. The Dynamics of Small-Scale Industries in the South. London: Intermediate Technology Publications, 71-83

Kotwal, A., B. Ramaswami, and W. Wadhwa (2011), Economic liberalization and Indian economic growth: What's the evidence? Journal of Economic Literature, 49(4): 1152-1199

Kucera, D. and L. Roncolato (2008), Informal employment: Two contested policy issues. International Labour Review, 147: 321-348

Maiti, D. (2008), The organizational morphology of rural industries and its dynamics in liberalized India: a study of West Bengal. Cambridge Journal of Economics, 32: 577-591.

Maloney, W. F. (2004), Informality Revisited. World Development 32(7): 1159-1178

Marjit, S. (2003), Economic reform and informal wage - a general equilibrium analysis. Journal of Development Economics, 72: 371-378

Mazumdar, D. and S. Sarkar (2008), Globalization, Labour Markets and Inequality in India. New York: Routeledge

Moser, C. N. (1978), Informal sector or petty commodity production: dualism or dependence in urban development. World Development, 6: 1041-1064

Mukim, M. (2011), Industry and the urge to cluster: a study on the informal sector in India. SERC Discussion Paper 72, Spatial Economics Research Center

Perry, G. E., W. F. Maloney, O. Arias, P. Fajnzylber, A. D. Mason, and J. SaavedraChanduvi (2007), Informality: Exit and exclusion. Washington, DC, World Bank

Portes, A., M. Castells, and L. A. Benton (1989), The informal economy: Studies in advanced and less developed countries. Baltimore, MD: Johns Hopkins University Press

Portes, A. (1994), When more labor can be less: labor standards, development and the informal economy. In: Rakowski C. (ed). Contrapunto. The informal sector debate in Latin America. Albany: State University of New York Press

Ramaswamy, K. V. (1999), The Search for Flexibility in Indian Manufacturing, New Evidence on Subcontracting Activities. Economic and Political Weekly, 34(6): 363368

Rani, U. and J. Unni (2011), Do Economic Reforms Influence Home-Based Work? Evidence from India. Feminist Economics, 15(3): 191-225

Ranis, G., and F. Stewart (1999), V-goods and the Role of the Urban Informal Sector in Development. Economic Development and Cultural Change, 47(2): 259-288 
Sahu, P. P. (2010), Subcontracting in India’s Unorganised Manufacturing Sector: A Mode of Adoption or Exploitation? Journal of South Asian Development, 5(1): 53-83

Sanyal, K. (2007), Rethinking Capitalist Development: Primitive Accumulation, Governmentality and Post-Colonial Capitalism. New Delhi: Routledge

Schneider, F., A. Buehn, and C. E. Montenegro (2010), New Estimates for the Shadow Economies all over the World. International Economic Journal, 24(4): 443-461

Siggel, E. (2010), The Indian informal sector: the impact of globalization and reform. International Labour Review, 149(1): 93-105

Tokman, V. E. (1978), An exploration into the nature of informal-formal sector relationships. World Development, 6(9-10): 1065-1075

Uchikawa, S. (2011), Linkage between organized and unorganized sectors in Indian Machinery Industry. Economic and Political Weekly, 44(1): 45-54

Wattanapruttipaisan, T. (2002), SME Subcontracting as Bridgehead to Competitiveness: Framework for An Assessment of Supply-side Capabilities and Demand-side Requirements. Asia-Pacific Development Journal, 9(1): 65-87

Weeks, J. (1975), Policies for Expanding Employment in the Informal Urban Sector of Developing Economies. International Labour Review, 111: 1-13 


\section{Appendix A: Tables and Figures}

Table A.1: Manufacturing 2-digit codes National Industrial Classification 1998

\begin{tabular}{cl}
\hline NIC code & Industry \\
\hline 15 & Manufacture of food products and beverages \\
16 & Manufacture of tobacco products \\
17 & Manufacture of textiles \\
18 & Manufacture of wearing apparel; dressing and dyeing of fur \\
19 & Tanning and dressing of leather; manufacture of luggage, handbags, saddlery, \\
& harness and footwear \\
20 & Manufacture of wood and wood and cork products, except furniture; manufacture \\
& of straw articles and plaiting materials \\
21 & Manufacture of paper and paper products \\
23 & Publishing, printing and reproduction of recorded media \\
24 & Manufacture of coke, refined petroleum products and nuclear fuel \\
25 & Manufacture of chemicals and chemical products \\
26 & Manufacture of rubber and plastics products \\
27 & Manufacture of other non-metallic mineral products \\
28 & Manufacture of basic metals \\
29 & Manufacture of fabricated metal products, except machinery and equipment \\
30 & Manufacture of machinery and equipment, n.e.c. \\
31 & Manufacture of electrical machinery and apparatus n.e.c. \\
32 & Manufacture of radio, television and communication equipment and apparatus \\
33 & Manufacture of medical, precision and optical instruments, watches and clocks \\
34 & Manufacture of motor vehicles, trailers and semi-trailers \\
35 & Manufacture of other transport equipment \\
36 & Manufacture of furniture; manufacturing n.e.c. \\
37 & Recycling \\
\hline &
\end{tabular}


Table A.2: Informal sector enterprise characteristics by modernity quartile

\begin{tabular}{cccc}
\hline & $1994-95$ & $2000-01$ & $2005-06$ \\
\hline Workers per enterprise & & 3.6 & 3.7 \\
Modernity quartile 1 & 4.0 & 3.8 & 3.8 \\
Modernity quartile 2 & 3.8 & 4.8 & 5.4 \\
Modernity quartile 3 & 5.6 & 8.1 & 9.4 \\
Modernity quartile 4 & 6.9 & & \\
Hired workers per enterprise & & 0.6 & 0.6 \\
Modernity quartile 1 & 0.5 & 0.9 & 0.9 \\
Modernity quartile 2 & 0.9 & 1.8 & 2.4 \\
Modernity quartile 3 & 2.3 & 4.8 & \\
Modernity quartile 4 & 3.3 & & 46.9 \\
Modernity quartile 1 & 35.3 & 46.0 & 116.0 \\
Modernity quartile 2 & 95.2 & 112.3 & 981.6 \\
Modernity quartile 3 & 240.9 & 227.9 & \\
Modernity quartile 4 & 440.1 & 703.9 & 43.1 \\
Assets per enterprise & & & 81.4 \\
Modernity quartile 1 & 34.2 & 38.9 & 184.3 \\
Modernity quartile 2 & 55.9 & 67.6 & 476.1 \\
Modernity quartile 3 & 119.4 & 116.2 & 295.2 \\
Modernity quartile 4 & 211.8 & & \\
Value added per enterprise & & & \\
Mote: Modernity measure is described in the main text. All values are averages across enterprises within each quartile, \\
calculated using survey weights. Assets and value added are measured in thousands real Rupees. Source: NSS survey of \\
unorganized manufacturing
\end{tabular}

Table A.3: Sample descriptive statistics

\begin{tabular}{lrrrrrr}
\hline Variables & \multicolumn{2}{c}{$1994-95$} & \multicolumn{2}{c}{$2000-01$} & \multicolumn{2}{c}{$2005-06$} \\
\hline Subcontracting formal & 19.96 & $(1.83)$ & 20.52 & $(2.00)$ & 21.04 & $(1.93)$ \\
Employment informal & 10.68 & $(1.90)$ & 10.93 & $(1.92)$ & 11.15 & $(1.79)$ \\
Hired workers informal & 9.3 & $(1.85)$ & 9.65 & $(1.87)$ & 9.82 & $(1.83)$ \\
Number of enterprises inf & 8.81 & $(2.15)$ & 9.09 & $(2.21)$ & 9.22 & $(2.12)$ \\
Wage bill informal & 18.94 & $(1.90)$ & 19.49 & $(1.87)$ & 19.91 & $(1.84)$ \\
$M$ & -0.06 & $(0.96)$ & 0.03 & $(0.98)$ & 0.03 & $(1.06)$ \\
Obs & 289 & & 300 & & 288 & \\
\hline
\end{tabular}

Note: All variables are in natural logs, except the modernity index $M$. Sample averages across state-industries, standard errors in parentheses. All values are in real Rupees. Sources: NSS survey of unorganized manufacturing, Annual Survey of Industries, and author's calculations. 
Figure A.1: Distribution of informal manufacturing employment across industries

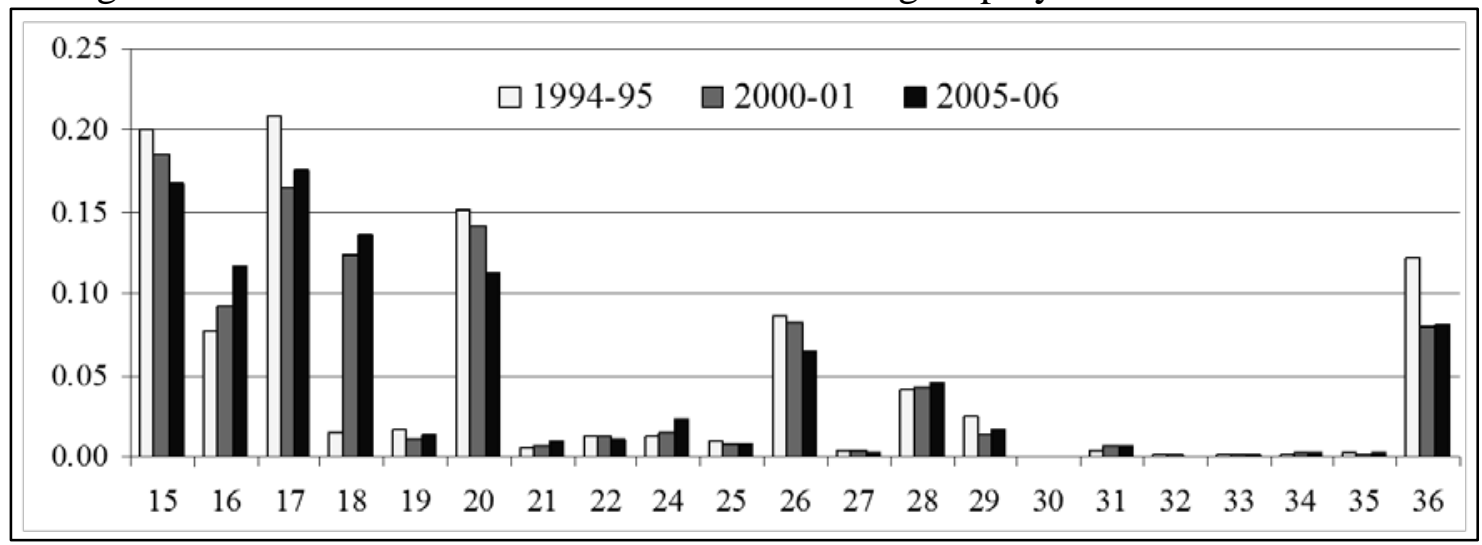

Note: Vertical axis shows share of total informal manufacturing employment, horizontal axis show industrial classification codes as listed in Table A.1. Source: NSS survey of unorganized manufacturing and author's calculations.

Figure A.2: Modernity by industry (all-India)

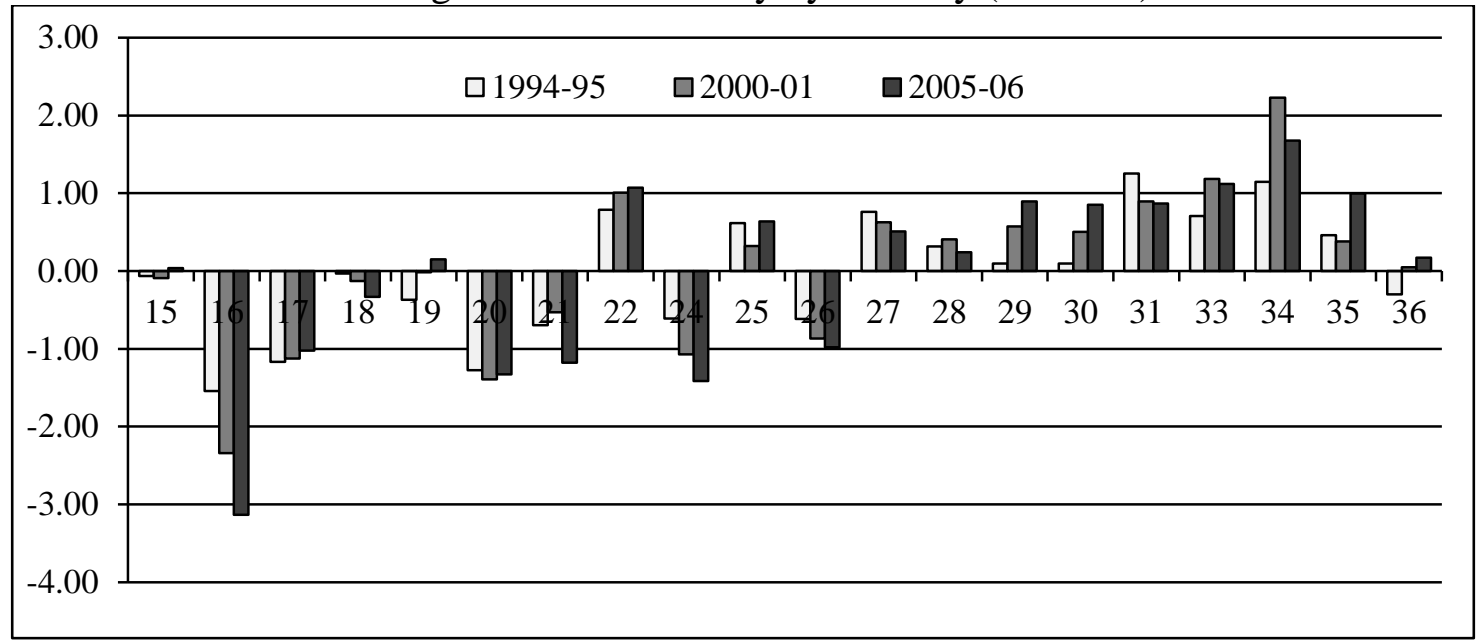

Note: modernity is measured as the log ratio of non-home-based to home-based enterprises in a given industry. Source: NSS survey of unorganized manufacturing.

Figure A.3: Formal sector subcontracting intensity by industry

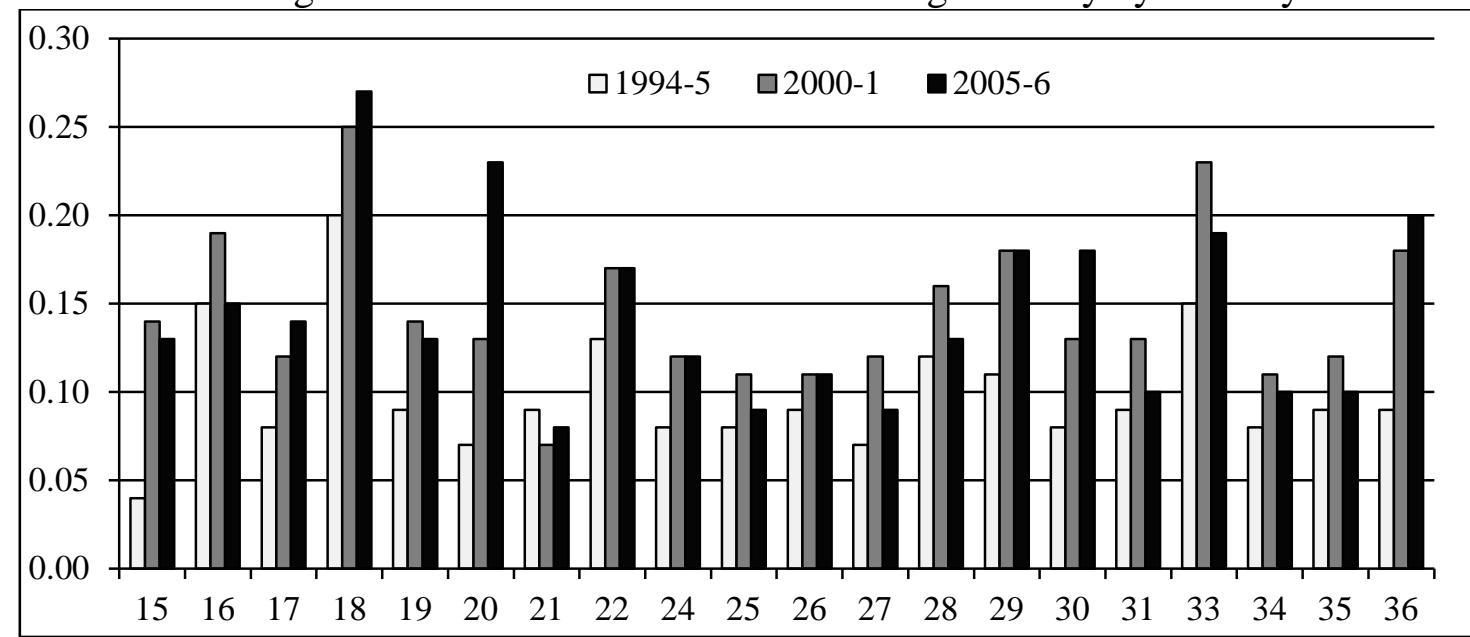

Note: Subcontracting to output ratio. Industrial classification codes as listed in Table A.1. Source: Annual Survey of Industries and authors' calculations. 


\section{Appendix B: Survey aggregates adjustment procedure}

The coverage of the NSS Unorganized Manufacturing survey varies somewhat over the years, and although this is captured in the survey weights provided by the NSS, the state and industry aggregate levels and growth of value added differ quite a bit from the National Accounts totals. These National Accounts totals are the official statistics used by the Indian government and are based on both the NSS survey of unorganized manufacturing and the Census of Small Scale Industrial Units. As there is most likely considerable measurement error in the survey measure of value added, the survey aggregates are adjusted using the published National Accounts data for GDP in unregistered manufacturing in the following manner. First, all-India unorganized sector GDP for each 2-digit industry is taken from the National Accounts. The survey-based distribution of each industry's value added across states is applied to this National Accounts aggregate in order to obtain value added by state-industry. State-industry employment is then calculated using the ratio of employment to value added of each state-industry from the NSS survey data, and similar adjustments are applied to the other outcome variables. For all outcome variables, the survey aggregates and the adjusted aggregates are highly correlated (around .95 in each year), but the survey aggregates are lower, both in levels and in growth. 